\title{
Pengaruh Kombinasi Substrat dan Lama Waktu Inkubasi Berbeda Fermentasi Menggunakan Aspergillus ficuum terhadap Aktivitas Enzim dan Perubahan Kandungan Nutrisi
}

\author{
W. A. Angga ${ }^{1}$, Y. Rizal ${ }^{2 *}$, M. E. Mahata ${ }^{2}$, A. Yuniza ${ }^{2}$, \& R. Mayerni ${ }^{3}$ \\ ${ }^{1}$ Mahasiswa Program Doktor, Universitas Andalas, Padang, Indonesia \\ ${ }^{2}$ Pengajar di Fakultas Peternakan, Universitas Andalas, Padang, Indonesia \\ ${ }^{3}$ Pengajar di Fakultas Pertanian, Universitas Andalas, Padang, Indonesia \\ Kampus Limau Manis, Kec. Pauh, Kota Padang, Sumatera Barat 25163 \\ *Email : yrizal@ansci.unand.ac.id
}

(Diterima : 14 Januari 2020; Disetujui : 03 Maret 2020)

\begin{abstract}
Physical processing such as immersion at different water temperatures did not improve crude fibre and crude protein content of wasted-tea leaves. Thus, the utilization of these wasted tea leaves for poultry diet is still limited due to the high in crude fibre content. Therefore, it is necessary to find out a method for solving this problem. One of the methods is a fermentation by using Aspergillus ficuum. This fungi is known as a microbe which produces cellulase for reducing fibre content. The objectives to investigate the appropriate rice bran (RB) and wasted tea leaf (WTL) combinations and incubation times when fermented with Aspergillus ficuum, and to study the effects of this fermentation process on enzymes (cellulase and protease) activity, and alteration of dry matter, crude fibre and crude protein contents. This experiment was performed in a completely randomized design in a $4 x 2$ factorial arrangement of treatments with 4 replicates. The first factor was RB and WTL combination as follows: 100:0\% (A1), 90:10\% (A2), 80:20\% (A3), 70:30\% (A4). The second factor was incubation times as follows: 7 days (B1) and 9 days (B2). These combinations of RB and WTL were fermented by using Aspergillus ficuum at the dose of $6.3 \times 10^{12} \mathrm{CFU} / \mathrm{mL}$. Measured variables were cellulase and protease activities, and alteration percentage in dry matter $(D M)$, crude fibre $(C F)$ and crude protein $(C P)$. There was an interaction between RB:WTL combination and incubation time in cellulase activity $(P<0.01)$ and $C F$ content $(P<0.01)$. Increasing WTL up to $10 \%$ in $R B$ : WTL combination significantly augmented $(P<0.05)$ cellulase activity at 9 days incubation time. The reduction percentage in $C F$ occurred at 90:10\% RB and TLM combination and 9 days incubation time. The incubation time for 9 days decreased the protease activity $(P<0.01)$ as well as the reduction percentage in DM $(P<0.05)$. The 90:10\% RB and WTL combination improved the increasing percentage in $C P(P<0.01)$. In conclusion, the appropriate $R B$ and WTL combination and incubation time for fermenting the combination ratio of RB:WTL by using Aspergillus ficuum was 90:10\% at 9 days incubation time.
\end{abstract}

Keyword: Aspergillus ficuum, enzyme activity, fermentation, nutrient alteration, rice bran, tea leaves.

\section{PENDAHULUAN}

Daun teh terbuang merupakan hasil samping dari aktivitas peremajaan tanaman teh, proses peremajaan ini dimaksudkan untuk menjaga tanaman teh selalu dalam fase vegetatif dan lebih produktif menghasilkan pucuk daun yang berkualitas dengan cara pemangkasan. Aktivitas pemangkasan menghasilkan daun teh terbuang yang jumlahnya cukup banyak dan selalu tersedia setiap tahun karena dilakukan setiap 3 tahun sekali dengan sistem rotasi, sehingga setiap harinya terdapat pemangkasan. Telah dilaporkan oleh Angga et al. (2018) bahwa produksi daun teh terbuang mencapai 25,03 ton/tahun dalam bentuk segar. Daun teh terbuang ini sangat berpotensi untuk dijadikan sebagai pakan karena kandungan gizi yang dimilikinya masih bermanfaat untuk ternak seperti kandungan protein, lemak, vitamin, mineral, karbohidrat dan senyawa alkalaloid lainnya (Ramkumar et al., 2011). Akan tetapi, dalam pemanfaatannya terkendala pada faktor pembatas pakan berupa serat kasar yang tinggi mencapai $17,40 \%$. Serat kasar yang tinggi dalam bahan pakan membuat daya cernanya rendah sehingga sulit dimanfaatkan oleh ternak. Serat kasar terdiri atas selulosa, hemiselulosa dan lignin (Tillman et al., 1998), ditambah lagi pada tanaman tua umumnya telah mengalami proses lignifikasi lanjut dimana terjadi ikatan selulosa oleh lignin dalam bentuk kristal lignoselulosa. Lignoselulosa ini merupakan penyusun dinding sel tanaman yang sukar untuk didegradasi karena monomer glukosanya berikatan dengan ikatan Beta-(1,4) (Ekinci et al., 2002). 
Dalam upaya untuk memperbaiki kualitas daun teh terbuang dilakukan fermentasi menggunakan mikroorganisme yang mampu mendegradasi serat kasar sebagai starternya. Salah satu mikroba yang memiliki kemampuan dalam menurunkan serat kasar adalah kapang Aspergillus ficuum. Kapang jenis ini mudah tumbuh dalam suasana aerob dan memiliki perkembangan yang cepat. Daun et al. (2015) menyatakan bahwa Aspergillus ficuum menghasilkan banyak enzim seperti acetylxilan esterase, selulase, dan xylosidase. Enzim selulase nantinya akan merombak serat kasar daun teh terbuang menjadi monomer yang lebih sederhana, sehingga mudah untuk dicerna oleh ternak. Selain mampu menghasilkan beberapa enzim seperti xylanase, phytase (Nair dan Duvnjak, 1990) dan tanase (Souza et al., 2015). Tanase merupakan enzim yang digunakan untuk mengkatalis reaksi pemutusan ikatan ester tanin terhidrolisis membentuk asam galat dan glukosa. Mengingat bahan yang digunakan adalah daun teh, maka kapang ini tepat untuk digunakan. Hal ini dikarenakan daun teh juga memiliki kandungan tanin yang cukup tinggi antara 11,76-15,14\% (Khasnabis et al., 2015). Belum banyak penelitian tentang penggunaan Aspergillus ficuum sebagai starter fermentasi bahan pakan ternak. Akan tetapi, pemanfaatan daun teh sebagai pakan cukup banyak dilaporkan seperti pada penelitian Krisnan (2005) menggunakan ampas teh fermentasi Aspergillus niger untuk ransum ayam broiler, pemberian daun teh tua dalam ransum broiler (Anita et al., 2012) dan ampas teh dalam bentuk pelet untuk pakan kelinci (Fiberty, 2002).

Tujuan penelitian ini adalah untuk mengukur perbandingan dedak padi dan daun teh terbuang dan lama waktu inkubasi yang tepatsaat difermentasidengan Aspergillusficuum berdasarkan aktivitas enzim dan persentase perubahan nutrien setelah fermentasi. Manfaat penelitian ini adalah dapat dijadikan rujukan dalam proses fermentasi daun teh terbuang menggunakan kapang Aspergillus ficuum.

\section{MATERI DAN METODE}

Penelitian ini dilaksanakan di Laboratorium Teknologi Pengolahan Pakan, Laboratorium Instrumen Teknologi Pertanian Universitas Andalas, yang dilaksanakan pada tanggal 21 Maret 2018 sampai 18 Juni 2018.

\section{Materi Penelitian}

Bahan-bahan yang diperlukan dalam penelitian ini meliputi dedak padi yang diperoleh dari tempat penggilingan padi yang berada di Pasar Baru (Kota Padang), daun teh diperoleh dari perkebunan teh yang berlokasi di Kabupaten Solok (Provinsi Sumatera Barat), kapang Aspergillus ficuum yang diperoleh dari Laboratorium Terpadu Institut Pertanian Bogor (IPB).

Alat-alat yang digunakan dalam penelitian ini adalah autoclave, pipet volumetrik, mikro pipet, inkubator, neraca analitik, sentrifuse dingin (Hitachi CR 21GIII), spektrofotometer, vortex mixer, corong Buchner, pompa vakum, laminar flow, kertas Whatman No. 42 dan peralatan gelas yang digunakan dalam laboratorium.

\section{Metode Penelitian}

- Desain penelitian: Metode yang digunakan dalam penelitian ini adalah metode eksperimen, yaitu metode fermentasi padat (Rizal et al., 2010), menggunakan Rancangan Acak Lengkap (RAL) pola faktorial $4 \times 2$ dengan 4 kali ulangan (Steel and Torrie, 1990), faktor pertama kombinasi dedak padi dan daun teh terbuang sebagai berikut: 100:0\% (A1), 90:10\% (A2), 80:20\% (A3), $70: 30 \%$ (A4). Faktor kedua waktu inkubasi adalah 7 hari (B1) and 9 hari (B2).

- Peubah yang diukur: adalah aktivitas enzim selulase dan protease, dan persentase perubahan kandungan bahan kering, serat kasar dan protein kasar daun teh terbuang.

- Persiapan Penelitian: Sebelum dilakukan fermentasi substrat berupa dedak padi dan daun teh terbuang yang telah dihaluskan 
ditimbang terlebih dahulu sesuai perlakuan, dimasukan ke dalam plastik poli-etilen, tambahkan air sampai kadarnya 60\% aduk hingga merata. Kemudian dilakukan sterilisasi dengan suhu $121^{\circ} \mathrm{C}$ selama 15 menit di dalam autoclave. Keluarkan substrat dari autoclave dan masukan ke dalam laminar flow tunggu suhunya turun sampai $45-50^{\circ} \mathrm{C}$, substrat kemudian diinokulasi dengan biakan murni Aspergillus ficuum pada dosis $6,3 \times 10^{12}$, lubangi plastik pada beberapa bagian (anaerob) dan di inkubasi selama 7 hari dan 9 hari sesuai perlakuan pada suhu kamar $\left(28^{\circ} \mathrm{C}\right)$ dengan $\mathrm{pH} 6$ di dalam incase.

\section{- Analisis aktivitas enzim}

Isolasi enzim kasar: Sebanyak $1 \mathrm{~g}$ sampel, rendam dengan $10 \mathrm{~mL}$ buffer phosphate 0,05 M pada $\mathrm{pH} 7$ dalam Erlenmeyer $250 \mathrm{~mL}$, masukan dalam inkubator shaker selama 2 jam pada suhu $27^{\circ} \mathrm{C}$ dengan kecepatan $100 \mathrm{rpm}$, saring dan ambil filtratnya, kemudian filtrat di sentrifuse pada kecepatan 5.000 rpm selama 15 menit setelah itu ambil supernatannya, didapatlah ekstrak enzim kasarnya.

Aktivitas enzim selulase: Mengacu pada metode Somogy-Nelson (Bergmeyer et al., 1981). $1 \mathrm{~mL}$ enzim kasar tambah $1 \mathrm{~mL}$ ekstrak $(0,5 \mathrm{~mL} \mathrm{CMC}+10 \mathrm{~mL}$ buffer phosphate), inkubasi selama 30 menit pada suhu $40^{\circ} \mathrm{C}$ dalam shaker water bath, ambil $1 \mathrm{~mL}$ tambah $1 \mathrm{~mL}$ nelson $\mathrm{AB}$, panaskan dalam air mendidih selama 20 menit, setelah dingin tambah $1 \mathrm{~mL}$ phosphatmolibdat tambah $7 \mathrm{~mL}$ akuades, baca pada panjang gelombang $575 \mathrm{~nm}$. Perhitungan:

Aktivitas enzim selulase $(\mathrm{U} / \mathrm{mL})=\frac{X \times P \times 1000}{T \times B M}$

Keterangan:

$$
\begin{array}{ll}
\mathrm{X} & \text { : Hasil konversi kurva standar } \\
\mathrm{P} & \text { : Pengenceran } \\
\mathrm{T} & \text { : Waktu } \\
\mathrm{BM} & \text { : Berat molekul glukosa }
\end{array}
$$

Aktivitas enzim protease: Mengacu pada metode Henriette et al. (1993). Pipet 2,5
$\mathrm{mL}$ larutan kasein 1\% dan timbang 1,5 mL buffer phosphate $(0,1 \mathrm{M} \mathrm{pH} \mathrm{7)}$ dalam tabung reaksi, campur dengan alat vortex, inkubasi dalam water bath $\left(37^{\circ} \mathrm{C}, 10\right.$ menit). Untuk blangko hentikan aktivitas enzim, dengan penambahan $5 \mathrm{~mL}$ larutan TCA $20 \%$, campur dengan menggunakan alat vortex, kemudian masukan kedalam kulkas selama 30 menit untuk menggumpalkan proteinnya. Sentrifuse (5.000 rpm, 15 menit, $4^{\circ} \mathrm{C}$ ), saring dan ambil supernatan. Pipet $2 \mathrm{~mL}$ supernatan kedalam tabung reaksi dan tambahkan $5 \mathrm{~mL} \mathrm{NaOH}$ $0,5 \mathrm{~N}$ dan $0,5 \mathrm{~mL}$ reagent Folin-Ciocalteu, biarkan 10 menit. Ukur absorbansinya dengan spektrofotometer pada panjang gelombang 650 nm. Perhitungan:

Aktivitas enzim protease $(\mathrm{U} / \mathrm{mL})=\frac{\mathrm{Y} \times \mathrm{a}}{b} \times \frac{1}{t}$

Keterangan:

Y : Absorbansi sampel

$a$ : Nilai a dari kurva regresi $Y: a+b x$

$\mathrm{b}$ : Nilai $\mathrm{b}$ dari kurva regresi $\mathrm{Y}: \mathrm{a}+\mathrm{bx}$

$\mathrm{t}$ : Waktu inkubasi.

- Penentuan kandungan BK, SK dan PK: Metode yang digunakan mengacu pada (AOAC, 1884).

- Penentuan persentase perubahan BK, SK dan PK: yaitu mencari selisih antara kandungan BK, SK atau PK setelah fermentasi dengan sebelum fermentasi dibagi dengan kandungan BK, SK atau PK sebelum fermentasi dan dikali $100 \%$.

- Pengolahan data: Data yang diperoleh dianalisis dengan sidik ragam dari RAL pola faktorial $4 \times 2$ dengan 4 ulangan. Jika terdapat perbedaan antar perlakuan, maka dilakukan uji lanjut dengan Duncan's Multiple Range/DMRT (Steel dan Torrie, 1990). 


\section{HASIL DAN PEMBAHASAN}

\section{Aktivitas Enzim}

Tabel 1. Pengaruh kombinasi dedak padi dan daun teh terbuang pada waktu inkubasi yang berbeda fermentasi menggunakan Aspergillus ficuum terhadap aktivitas enzim selulase dan protease.

\begin{tabular}{|c|c|c|c|c|c|c|}
\hline \multirow{2}{*}{ Aktivitas enzim } & \multirow{2}{*}{$\begin{array}{c}\text { Waktu } \\
\text { inkubasi }\end{array}$} & \multicolumn{4}{|c|}{ Kombinasi dedak padi dan daun teh terbuang (\%) } & \multirow{2}{*}{ Rata-rata } \\
\hline & & 100 & $90: 10$ & $80: 20$ & $70: 30$ & \\
\hline \multirow{3}{*}{$\begin{array}{l}\text { Selulase } \\
(\mathrm{U} / \mathrm{mL})\end{array}$} & 7 hari & $4,397 \pm 0,35^{\mathrm{c}}$ & $4,103 \pm 0,06^{c}$ & $3,384 \pm 0,16^{\mathrm{d}}$ & $2,279 \pm 0,11^{\mathrm{e}}$ & $3,541^{b}$ \\
\hline & 9 hari & $6,352 \pm 0,11^{a}$ & $6,180 \pm 0,15^{a}$ & $4,863 \pm 0,30^{b}$ & $3,586 \pm 0,28^{d}$ & $5,245^{\mathrm{a}}$ \\
\hline & Rata-rata & $5,374^{\mathrm{a}}$ & $5,141^{\mathrm{b}}$ & $4,123^{c}$ & $2,933^{\mathrm{d}}$ & \\
\hline \multirow{3}{*}{$\begin{array}{l}\text { Protease } \\
(\mathrm{U} / \mathrm{mL})\end{array}$} & 7 hari & $0,40 \pm 0,01$ & $0,41 \pm 0,06$ & $0,40 \pm 0,03$ & $0,39 \pm 0,03$ & $0,40^{\mathrm{b}}$ \\
\hline & 9 hari & $0,45 \pm 0,08$ & $0,52 \pm 0,03$ & $0,43 \pm 0,03$ & $0,46 \pm 0,08$ & $0,46^{a}$ \\
\hline & Rata-rata & 0,43 & 0,46 & 0,41 & 0,42 & \\
\hline
\end{tabular}

\section{a. Aktivitas enzim selulase}

Terdapat interaksi $(\mathrm{P}<0,01)$ antara kombinasi DP:DTT dengan lama waktu inkubasi. Kombinasi dedak padi dan daun teh terbuang juga berpengaruh sangat nyata $(\mathrm{P}<0,01)$ terhadap aktivitas selulase, demikian pula dengan lama waktu inkubasi $(\mathrm{P}<0,01)$. Pada penelitian ini penambahan daun teh $10 \%$ pada lama waktu inkubasi 9 hari meningkatkan aktivitas selulase, tetapi jika ditambahkan 20\% atau lebih terjadi penurunan aktivitas selulase kembali. Peningkatan aktivitas enzim selulase seperti yang terlihat pada Tabel 1. Unit aktivitas enzim tertinggi diperoleh pada inkubasi 9 hari dengan substrat $100 \%$ dedak padi dengan unit yang diperoleh $6,352 \mathrm{U} / \mathrm{mL}$, terdapat kecenderungan penurunan aktivitas selulase pada penambahan daun teh, penambahan daun teh sebanyak $10 \%$ masih memiliki aktivitas yang sama $(6,180 \mathrm{U} / \mathrm{mL})$. Temuan ini lebih tinggi dari hasil penelitian (Sugiwati et al., 2018) mendapatkan aktivitas enzim Aspergillus niger pada fermentasi dedak padi yaitu sebesar 5,24 U/mL dan (Gilna dan Khaleel, 2011) aktivitas enzim selulase yang diperoleh adalah $5,84 \mathrm{U} / \mathrm{mL}$ dari Aspergillus fumigatus pada fermentasi substrat lignoselulsosa. Seiring dengan bertambahnya persen penggunaan daun teh terlihat jelas penurunannya. Hal ini dikarenakan sumber karbon dari dedak padi yang tinggi dapat digunakan untuk pertumbuhan dan perkembangan kapang, sedangkan dengan meningkatnya persen daun teh, maka jumlah persen karbonnya semakin menurun, dimana daun teh merupakan sumber nitrogen. Dalam fermentasi sumber nitrogen juga perlu ditambahkan dan diperuntukkan untuk mendukung pertumbuhan dan perkembangan kapang, akan tetapi jumlahnya tidak banyak. Hal ini sesuai dengan pendapat Mulyani (2016) selama proses fermentasi ada sejumlah protein yang digunakan oleh kapang Rhizopus oligosporus sebagai sumber nitrogen untuk pertumbuhannya. Purkan et al. (2015) menyatakan dengan meningkatnya suhu pada saat proses fermentasi menyebabkan terjadinya kenaikan kecepatan reaksi enzimatis dikarenakan bertambahnya energi kinetik. Energi tersebut mampu meningkatkan tabrakan antara molekul-molekul sehingga terbentuk kompleks enzim substrat yang stabil yang mengakibatkan aktivitas enzim meningkat. Peningkatan aktivitas selulase diimbangi oleh faktor sifat mikroorganisme terhadap lingkungan, kandungan nutrisi, suhu, $\mathrm{pH}$, dan jumlah substrat (Kusuma et al., 2019). Selain itu, disebabkan juga mikroorganisme yang terdapat dalam sampel tersebut mampu mendegradasi substrat secara optimal menggunakan selulosa sebagai nutrisi utamanya (Mrudula dan Murugammal, 2011).

\section{b. Aktivitas enzim protease}

Aktivitas protease tidak terdapat interaksi $(\mathrm{P}>0,05)$ antara kombinasi DP:DTT dengan lama waktu inkubasi yang berbeda. Namun, lama waktu inkubasi terdapat pengaruh sangat nyata $(\mathrm{P}<0,01)$ terhadap peningkatan aktivitas protease. Seperti ditunjukkan pada Tabel 1, 
unit peningkatan aktivitas protease terbaik diperoleh pada lama waktu inkubasi 9 hariyaitu 0,46 U/mL. Hasil ini sama dengan penelitian Bekalu et al. (2017) pada fermentasi gandum menggunakan Aspergillus ficuum diperoleh aktivitas $0,4 \mathrm{U} / \mathrm{mL}$ akan tetapi dicapai pada waktu 7 hari. Hal tersebut menandakan bahwa pada waktu inkubasi 9 hari diduga Aspergillus ficuum dalam fase logaritmik. Menurut Madigan et al. (2012) enzim digolongkan sebagai metabolit primer yang biasanya dibentuk pada fase pertumbuhan logaritmik. Pada fase ini pertumbuhan sel akan terjadi dengan cepat dan produksi enzim akan meningkat. Bentubo dan Gompertz (2014) menyatakan inkubasi adalah waktu yang diperlukan enzim untuk berikatan dengan substrat, jika waktu inkubasinya singkat maka aktivitas enzim akan rendah karena singkatnya waktu berinteraksi yang mengakibatkan interaksi tidak berlangsung secara keseluruhan sehingga produk yang dihasilkan sedikit juga. Jika dilihat pada Tabel 1, aktivitas protease pada substrat yang mengandung daun teh mengalami peningkatan meskipun tidak memberikan pengaruh yang nyata. Daun teh mengandung protein yang cukup untuk dijadikan sebagai sumber nitrogen untuk perkembangan kapang. Menurut Putri et al. (2015) sel dapat mensintesis protease sebagai reaksi terhadap senyawa pemicu (inducer) pada medium. Protease termasuk enzim yang bersifat indusibel karena sintesisnya memerlukan inducer yaitu protein. Adanya protein pada medium menyebabkan sel mensintesis protease. Indra et al. (2015) melaporkan aktivitas enzim protease dari Aspergillus flavus pada fermentasi legum semakin tinggi aktivitasnya pada lama inkubasi 7 hari sampai dengan 1,94 $\mathrm{U} / \mathrm{mL}$.

\section{Perubahan Kandungan Nutrien}

Tabel 2. Pengaruh kombinasi dedak padi dan daun teh terbuang pada waktu inkubasi yang berbeda fermentasi menggunakan Aspergillus ficuum terhadap kandungan nutrisi.

\begin{tabular}{|c|c|c|c|c|c|c|}
\hline \multirow{2}{*}{$\begin{array}{c}\text { Kandungan } \\
\text { nutrisi }\end{array}$} & \multirow{2}{*}{ Waktu inkubasi } & \multicolumn{4}{|c|}{ Kombinasi dedak padi dan daun teh terbuang (\%) } & \multirow[t]{2}{*}{ Rata-rata } \\
\hline & & 100 & 90:10 & $80: 20$ & $70: 30$ & \\
\hline \multirow{3}{*}{$\begin{array}{c}\text { Bahan Kering } \\
(\%)\end{array}$} & 7 hari & $2,30 \pm 0,24$ & $1,47 \pm 0,41$ & $1,37 \pm 0,23$ & $1,72 \pm 1,43$ & $1,72^{b}$ \\
\hline & 9 hari & $2,88 \pm 1,55$ & $2,45 \pm 0,88$ & $2,26 \pm 0,58$ & $2,23 \pm 0,25$ & $2,46^{\mathrm{a}}$ \\
\hline & Rata-rata & 2,59 & 1,96 & 1,82 & 1,97 & \\
\hline \multirow{3}{*}{$\begin{array}{c}\text { Serat Kasar } \\
(\%)\end{array}$} & 7 hari & $44,31 \pm 1,13^{\mathrm{bc}}$ & $44,96 \pm 0,49^{\mathrm{b}}$ & $44,91 \pm 2,21^{\mathrm{b}}$ & $28,22 \pm 1,23^{\mathrm{e}}$ & $40,60^{\text {ba }}$ \\
\hline & 9 hari & $55,33 \pm 1,26^{a}$ & $53,83 \pm 0,41^{a}$ & $42,62 \pm 1,14^{c}$ & $34,28 \pm 1,28^{d}$ & $46,51^{\mathrm{a}}$ \\
\hline & Rata-rata & $49,82^{\mathrm{a}}$ & $49,39^{a}$ & $43,77^{\mathrm{b}}$ & $31,25^{c}$ & \\
\hline \multirow{3}{*}{$\begin{array}{c}\text { Protein Kasar } \\
\qquad(\%)\end{array}$} & 7 hari & $13,51 \pm 0,32$ & $17,38 \pm 0,21$ & $12,31 \pm 0,06$ & $10,57 \pm 0,48$ & 13,44 \\
\hline & 9 hari & $13,56 \pm 0,08$ & $17,90 \pm 0,19$ & $12,17 \pm 0,20$ & $10,60 \pm 0,17$ & 13,56 \\
\hline & Rata-rata & $13,53^{\mathrm{b}}$ & $17,64^{a}$ & $10,58^{c}$ & $12,24^{\mathrm{d}}$ & \\
\hline
\end{tabular}

Keterangan: ${ }^{a, b, c, d, e}$ Superskrip yang berbeda pada baris dan kolom yang sama menunjukkan pengaruh yang berbeda nyata $(\mathrm{P}<0,05)$.

\section{a. Bahan kering}

Pada perubahan bahan kering tidak terjadi interaksi $(\mathrm{P}>0,05)$ antara kombinasi DP:DTT dengan lama waktu inkubasi yang berbeda. Akan tetapi, lama waktu inkubasi menurunkan $(\mathrm{P}<0,05)$ kandungan bahan kering. Persentase penurunan bahan kering terjadi pada lama waktu inkubasi 9 hari dengan nilai 2,46\%. Penurunan kandungan bahan kering dikarenakan meningkatnya kadar air setelah fermentasi. Affandi dan Yuniati (2011) melaporkan pada fermentasi ampas kelapa menggunakan kapang Rhizopus oligosporus mengalami peningkatan kadar air setelah diinkubasi selama 3 hari sebesar 26\%. Produk yang dihasilkan dari fermentasi, selain etanol dan gas $\mathrm{CO}_{2}$ adalah asam asetat, asam butirat, asam laktat, asetaldehida dan lain-lain (Paul, 1980). Meningkatnya persentase penurunan bahan kering pada lama 9 hari disebabkan oleh semakin lama proses fermentasi maka akan semakin banyak kandungan nutrien yang terdegradasi oleh kapang sebagai substrat untuk perkembangan tubuhnya, penggunaan substrat oleh mikroba sebagai sumber karbon, nitrogen dan mineral kemudian melepaskan $\mathrm{CO}_{2}$ dan energi dalam bentuk panas yang 
menguap bersama partikel air $\left(\mathrm{H}_{2} \mathrm{O}\right)$, molekul air terbentuk dari proses katabolisme yang merombak senyawa kompleks menjadi bahan yang lebih sederhana (Zumael, 2009). Pada penelitian Styawati et al. (2014) fermentasi daun nanas menggunakan jamur Trametes sp dengan waktu inkubasi 2 hari sampai dengan 6 hari mengalami penurunan bahan kering yang signifikan. Hal tersebut terjadi karena semakin lama waktu yang digunakan maka terjadi proses fermentasi yang menyebabkan kandungan nutrien banyak yang terurai dan proses fermentasi ini meningkatkan kadar air. Hal ini sesuai dengan pendapat Astuti et al. (2017) yang menyatakan peningkatan kandungan air selama fermentasi menyebabkan kandungan bahan kering substrat menurun sehingga menyebabkan kehilangan bahan kering. Semakin tinggi air yang dihasilkan selama fermentasi maka kehilangan bahan kering semakin meningkat. Oleh karena itu, peningkatan kehilangan bahan kering juga dipengaruhi oleh peningkatan kadar air yang berasal dari fermentasi gula sederhana.

\section{b. Serat kasar}

Terdapat interaksi $(\mathrm{P}<0,01)$ antara kombinasi DP:DTT dengan lama waktu inkubasi yang berbeda. Kombinasi DP:DTT dan lama waktu inkubasi berpengaruh sangat nyata $(\mathrm{P}<0,01)$ terhadap penurunan kandungan serat kasar. Penurunan serat kasar tertinggi pada lama inkubasi 9 hari dengan substrat $100 \%$ dedak padi yaitu 55,53\% dan kombinasi DP:DTT 90:10\% yaitu (53,83\%). Hasil ini lebih tinggi dari penelitian Maulana et al. (2019) melaporkan pada fermentasi ampas susu kedelai yang difermentasi dengan Aspergillus ficuum mampu menurunkan kandungan serat kasar sampai dengan 10,29\%. Semakin lama proses fermentasi maka serat kasar akan semakin menurun, hal ini dikarenakan meningkatnya kesempatan Aspergillus ficuum dalam mendegradasi serat kasar dari substrat perlakuan. Penurunan serat kasar seiring dengan meningkatnya aktivitas enzim selulase. Dimana enzim selulase merupakan enzim yang memutuskan ikatan glikosidik Beta-1,4 di dalam selulosa, siklodekstrin, selobiosa, dan turunan selulosa lainnya (Sudaryati dan Sastraatmadja, 1993). Kadar serat kasar mengalami penurunan sebagai akibat dari berkurangnya kandungan lignin dan hemiselulosa dalam bahan. Penguraian hemiselulosa menjadi xilan dan gula sederhana lainnya juga menyebabkan turunnya kandungan serat kasar dalam bahan. Struktur hemiselulosa dibagi menjadi empat kelompok berdasarkan komposisi rantai utamanya yaitu (1) D-xylanyaitu 1-4 Betaxylosa; (2) D-manan yaitu (1-4) Beta-D-mannosa; (3) D-xyloglucan dan (4) D-galactan yaitu 1-3 BetaD-galaktosa (Izydorczyk et al., 2005). Tidak hanya itu Aspergillus ficuum juga menghasilkan enzim xylanase yang mampu mendegradasi xilan yang merupakan komponen dari serat kasar (Lu et al., 2008). Pada penelitian (Widjaja, 2008), menyatakan Aspergillus niger dapat menghasilkan enzim xilanase yang mampu mendegradasi hemiselulosa terbesar 32,83\% dan degradasi lignin sebesar 23,12\% pada proses biobleaching industri kertas. Keadaan ini menunjukkan bahwa kapang selulolitik dapat mendegradasi komponen lignoselulosa secara acak. Gushairiyanto, (2004) melaporkan fermentasi kulit umbi ketela pohon oleh Aspergillus niger pada dosis 0,2\% selama 96 jam menurunkan serat kasar dari 32,07\% menjadi 23,66\%. Tampoebolon (2009) melaporkan fermentasi Aspergillus niger (4\%) dengan ampas sagu selama 12 hari dapat meningkatkan kadar protein yaitu sebesar $7,04 \%$ dan kadar serat kasar menurun sebesar $12,81 \%$.

\section{c. Protein kasar}

PerlakuankombinasiDP:DTT denganlama waktu inkubasi yang berbeda pada fermentasi menggunakan Aspergillus ficuum tidak terdapat interaksi $(\mathrm{P}>0,05)$ terhadap kandungan protein kasar. Akan tetapi, kombinasi DP:DTT terdapat pengaruh sangat nyata $(\mathrm{P}<0,01)$ terhadap peningkatan protein kasar. Kombinasi DP:DTT (90:10\%) menghasilkan persentase tertinggi pada peningkatan protein kasar yaitu dengan nilai $17,64 \%$. Temuan ini lebih tinggi dari penelitian Wahyuni (2003) pada fermentasi dedak padi menggunakan kapang Aspergillus ficuum dengan substrat dedak padi, dengan peningkatan protein kasar 15,18\%. Peningkatan kandungan protein kasar dikarenakan adanya peningkatan pertumbuhan kapang sejalan dengan lama waktu inkubasi dan juga substrat yang digunakan merupakan sumber protein 
kasar, penggunaan daun teh sebagai campuran substrat juga merupakan sumber nitrogen bagi pertumbuhan kapang tersebut. Daun teh juga mengandung protein kasar cukup tinggi sampai dengan 19,63\% (Angga et al., 2018). Pada $100 \%$ dedak padi hanya sedikit peningkatan protein kasar (13,53\%), hal tersebut disebabkan tidak adanya sumber nitrogen yang diberikan untuk pertumbuhan kapang (Septiana dan Simanjuntak, 2017). Menurut Noferdiman et al. (2008) peningkatan kandungan protein kasar beriringan dengan peningkatan pertumbuhan kapanghalinidikarenakantubuhdarikapangitu sendiri merupakan elemen yang mengandung nitrogen. selain itu, enzim yang dihasilkan dari proses fermentasi (enzim ekstra seluler) dari kapang tersebut juga merupakan protein sel tunggal biomassa sel yang mengandung sekitar 40-65\% protein, sehingga bisa menyumbang sebagai protein kasar (Oboh dan Oladunmoye, 2007). Sedangkan pada kombinasi 80:20\% dan $70: 30 \%$ juga rendah peningkatan protein kasarnya. Hal ini dikarenakan pada keduanya memiliki aktivitas enzim yang rendah sehingga protein yang dihasilkannya juga rendah.

\section{KESIMPULAN}

Kombinasi dedak padi dan daun teh terbuang, dan waktu inkubasi yang tepat untuk memfermentasi daun teh terbuang menggunakan Aspergillus ficuum adalah 90:10\% pada lama waktu inkubasi 9 hari, dengan aktivitas enzim selulase yang tinggi (6,180 U/ $\mathrm{mL})$, persentase penurunan kandungan serat kasar $(53,83 \%)$, dan peningkatan persentase kandungan protein kasar $(17,90 \%)$.

\section{UCAPAN TERIMAKASIH}

Penelitian ini di danai oleh Kementerian Riset, Teknologi, dan Pendidikan Tinggi Republik Indonesia melalui PMDSU No: 324 / SP2H / LT / DRPM / IX / 2017 kami sangat berterima kasih kepada Menteri Riset, Teknologi, dan Pendidikan Tinggi Republik Indonesia, Indonesia dan Rektor Universitas Andalas atas dukungannya.

\section{DAFTAR PUSTAKA}

Affandi, E. \& H. Yuniati. 2011. Uses of the waste of palm residue as substrate for syinthesizing some nutrients through Rhizopus oligosporus fermentation. PGM. 34(2) : 123-130.

Angga, W. A., Y. Rizal, M. E. Mahata, A. Yuniza, \& R. Mayerni. 2018. Potential of waste tea leaves (Camellia sinensis) in West Sumatra to be processed into poultry feed. Pakistan Journal of Nutrition. 17(6) : 287-293. https://doi. org/10.3923/pjn.2018.287.293.

Anita, W. Y., Suharto, \& I. Astuti. 2012. Pengaruh pemberian tepung daun teh tua dalam ransum terhadap performan dan persentase lemak abdominal ayam broiler. Tropical Animal Husbandry. 1(1) : 1-6.

AOAC. 1884. Official Methods of Analysis. Association of Official Analytical Chemists. Washington DC.

Astuti, T., M. N. Rofiq, \& N. Nurhaita. 2017. Evaluasi kandungan bahan kering, bahan organik dan protein kasar pelepah sawit fermentasi dengan penambahan sumber karbohidrat. Jurnal Peternakan. 14(2) : 42. https://doi. org/10.24014/jupet.v14i2.4247.

Bekalu, Z. E., C. K. Madsen, G. Dionisio, \& H. Brinch-Pedersen. 2017. Aspergillus ficuum phytase activity is inhibited by cereal grain components. PLoS ONE. 12(5) : 1-13. https:// doi.org/10.1371/journal.pone.0176838.

Bentubo, H. D. L. \& O. F. Gompertz. 2014. Effects of temperature and incubation time on the in vitro expression of proteases, phospholipases, lipases and DNases by different species of Trichosporon. SpringerPlus. 3(1) : 1-10. https:// doi.org/10.1186/2193-1801-3-377.

Bergmeyer, H. U., J. Bergmeyer, \& M. Grab. 1981. Methods of Enzymatic Analysis 2 (2nd ed., Vol. 2). https://doi.org/https://doi.org/10.1016/ B978-0-12-091302-2.X5001-4.

Daun, K., N. A. M. Eskin, \& D. Hickling. 2015. Canola: Chemistry, Production, Processing, and Utilization (J. K. Daun, D. Hickling, \& M. Eskin, eds.). United States of America: AOCS.

Ekinci, M. S., J. C. Martin, \& H. J. Flint. 2002. Expression of a cellulase gene, celA, from the rumen fungus Neocallimastix patriciarum in Streptococcus bovis by means of promoter fusions. Biotechnology Letters. 24(9) : 735-741. https://doi.org/10.1023/ A:1015250504093.

Fiberty, E. 2002. Pengaruh Beberapa Tingkat Penggunaan Ampas Teh dalam Ransum Bentuk Pelet terhadap Performan Kelinci Persilangan Lepas Sapih. Pdf. Institut Pertanian Bogor. Bogor.

Gilna, V. V. \& K. M. Khaleel. 2011. Cellulase enzyme activity of Aspergillus fumigatus from mangrove soil on lignocellulosic substrate. Recent Research in Science and Technology. 3(1) : 132-134. 
Gushairiyanto. 2004. Fermentasi Kulit Umbi Ketela Pohon oleh Aspergillus niger serta Implikasinya Terhadap Kambing Kacang Jantan. Universitas Padjadjaran. Bandung.

Henriette, C., S. Zibeni, \& M. E. A. Petitdemange. 1993. Protease and lipase production by a strain of Setaria marcessen. Journal of Industrial Microbiology. 12 : 129-135.

Indra, P., R. Isworo, \& Wijanarka. 2015. Produksi enzim protease Aspergillus Flavus Pam-25 dengan variasi $\mathrm{pH}$ dan waktu inkubasi. Jurnal Biologi. 4(2) : 10-16.

Izydorczyk, M. S., A. Canada, S. W. Cui, A. Canada, Q. Wang, \& A. Canada. 2005. Polysaccharide Gums: Structures, Functional Properties, and Applications. In Food Carbohydrates: Chemistry, Physical Properties and Aplications, FL: Taylor \& Francis, PP. 263-307.

Khasnabis, J., C. Rai, \& A. Roy. 2015. Determination of tannin content by titrimetric method from different types of tea. Journal of Chemical and Pharmaceutical Research. 7(6) : 238-241.

Krisnan, R. 2005. Pengaruh pemberian ampas teh (Camellia sinensis) fermentasi dengan Aspergillus niger pada ayam broiler. JITV. 10(1) : 1-5. https:/ / doi.org/10.1111/1556-4029.12060.

Kusuma, A. P., S. Chuzaemi, \& Mashudi. 2019. The effect lenght of fermentation of pineapple fruit waste (Ananas comosus L. Merr ) on the physical quality and nutrient content using Aspergillus niger. Jurnal Nutrisi Ternak Tropis. 2(1) : 1-9.

Lu, F., M. Lu, Z. Lu, X. Bie, H. Zhao, \& Y. Wang. 2008. Purification and characterization of xylanase from Aspergillus ficuum AF-98. Bioresource Technology. 99(13) : 5938-5941. https://doi. org/10.1016/j.biortech.2007.10.051.

Madigan, M., J. M. Martinko, D. Stahl, \& D. P. Clark. 2012. Biology of Microorganism (13th Ed). Prentice-Hall Internastional Inc. Wisconsin.

Maulana, Z., Mirnawati, \& C. Gita. 2019. Pengaruh Dosis Inokulum Aspergillus ficuum dan Lama Fermentasi Terhadap Aktivitas Selulase, Serat Kasar dan Daya Cerna Serat Kasar Ampas Susu Kedelai Fermentasi. Universitas Andalas. Padang.

Mrudula, S., \& R. Murugammal. 2011. Production of cellulase by Aspergillus niger under submerged and solid state fermentation using coir waste as a substrate. Brazilian Journal of Microbiology. 42(3) : 1119-1127. https://doi.org/10.1590/ S1517-83822011000300033

Mulyani, S. 2016. Effect of Fermentation time to the protein levels of fermented lamtoro gung (Leucaena leucocephala) fruit seed. Akad. Kim. 5 :50-54.

Nair, V. C. \& Z. Duvnjak. 1990. Reduction of phytic acid content in canola meal by Aspergillus ficuum in solid state fermentation process. Appied Microbiology and Biotechnology. 34 : 183-188. https://doi.org/10.1016/B978-0-12384677-8.00009-6.
Noferdiman, Y. Rizal, Mirzah, Y. Heryandi, \& Y. Marlinda. 2008. Penggunaan urea sebagai sumber nitrogen pada proses biodegradasi substrat lumpur sawit oleh jamur Phanerochaete chrysosporium. Jurnal Ilmiah Ilmu-Ilmu Peternakan. 11(4) : 75-82.

Oboh, G. \& M. K. Oladunmoye. 2007. Biochemical changes in micro-fungi fermented cassava flour produced from low- and mediumcyanide variety of cassava tubers. Nutrition and Health. 18(4) : 355-367. https://doi. org/10.1177/026010600701800405.

Paul, J. K. 1980. Large and Small Scale Ethyl Alcohol Manufacturing Processes From Agricultural Raw Materials. In Chemical Technology Review (1st Ed.). https://doi. org/10.1016/0361-3658(81)90031-x.

Purkan, H., H. Purnama, \& S. Sumarsih. 2015. Produksi enzim selulase dari Aspergillus niger menggunakan sekam padi dan ampas tebu sebagai induser. Jurnal Ilmu Dasar. 16(2) : 95102.

Putri, R. M., R. Isworo, \& P. Sri. 2015. Produksi enzim protease dari $A$. niger PAM18A dengan variasi $\mathrm{pH}$ dan waktu inkubasi. Jurnal Biologi. $4(2): 25-34$.

Ramkumar, S., P. Sureshkumar, A. K. A. Mandal, K. Rajaram, \& P. Mohankumar. 2011. Identification of superior varieties of tea (Camellia sinensis (L.) o. kuntze) in the selected UPASI germplasm using biomarkers. International Journal of the Physical Sciences. 6(5) : 727-743. https://doi.org/10.5897/ JMPR11.1243.

Rizal, Y., Mirnawati, Y. Marlida, \& I. P. Kompiang. 2010. The role of humic acid in palm kernel cake fermented by Aspergillus niger for poultry ration. Pakistan Journal of Nutrition, 9(2) : 182-185. https://doi.org/10.3923/ pjn.2010.182.185.

Septiana, E. \& P. Simanjuntak. 2017. Pengaruh kondisi kultur yang berbeda terhadap aktivitas antioksidan metabolit sekunder kapang Endofit asal akar kunyit. Traditional Medicine Journal. 22(April) : 31-36.

Souza, P. N. da C., N. D. C. Maia, L. H. S. Guimarães, M. L. V. de Resende, \& P. G. Cardoso. 2015. Optimization of culture conditions for tannase production by Aspergillus sp. gm4 in solid state fermentation. Acta Scientiarum. Biological Sciences, 37(1) : 23. https://doi.org/10.4025/ actascibiolsci.v37i1.22731.

Steel, R. G. D., \& J. H. Torrie. 1990. Principles and procedure of statistics: A biometrical approach. In Computers E Geosciences. https:/ / doi.org/10.1016/0098-3004(83)90054-7.

Styawati, N. E., Mutharudin, \& Liman. 2014. Pengaruh lama fermentasi Trametes sp. terhadap kadar bahan kering, kadar abu, dan kadar serat kasar daun nenas varietas Smooth Cayene. Jurnal Ilmiah Peternakan Terpadu. 2(1) : 19-24. 
Sudaryati, Y. \& D. Sastraatmadja. 1993. Seleksi strain Aspergillus spp. untuk menghasilkan enzim selulase dalam media dedak. Jurnal Mikrobiologi Indonesia. 3 : 30-32.

Sugiwati, S., M. T. Suhartono, M. Hanafi, \& H. N. Lioe. 2018. Produksi $\beta$-glukosidase Aspergillus niger BIO 2173 dengan Fermentasi padat menggunakan substrat dedak. Jurnal Selulosa, $8(1)$ : 33. https://doi.org/10.25269/jsel. v1i01.221.

Tampoebolon, B. I. M. 2009. Kajian perbedaan aras dan lama pemeraman fermentasi ampas sagu dengan Asperigillus niger terhadap kandungan protein kasar dan serat kasar. Seminar Nasional Kebangkitan Peternakan. 235-243.
Tillman, A. D., H. Hartadi, S. Reksohadiprodjo, S. Prawirokusumo, \& S. Lebdosoekojo. 1998. Ilmu Makanan Ternak Dasar. Gadjah Mada University Press. Yogyakarta.

Wahyuni, S. 2003. Fermentasi dedak padi oleh kapang Aspergillus ficuum dan pengaruhnya terhadap kadar fitat, kualitas protein kasar serta energi metabolis pada ayam. Jurnal Bionatura. 5(2) : 141-149.

Widjaja, A. 2008. Pengurangan Kadar Lignin Ramah Lingkungan pada Industri Pulp dan Kertas oleh Enzim Xilanase dari Aspergillus niger. Digilib.Its.Ac.Id: 1-10.

Zumael, Z. 2009. The Nutrient Enrichment of Biological Processing. Agricmed, Warsaw. 